\title{
Original article \\ Territorial disputes, identity conflicts, and violence in surfing
}

\author{
Marília Martins Bandeira \\ State University of Campinas, Brazil
}

\begin{abstract}
Aggressive manifestations of localism are a current concern among surfers and are becoming well known as a result of specialized media. The objective of this paper was to investigate this phenomenon through the examination of a specific case and empirical fieldwork that was conducted for an ethnography of São Paulo surfers. The data were obtained via participant observations and open interviews. The results indicate that conflicts generally begin as disputes over the best waves. Surfing has a general rule of "wave priority criteria," based on spatial positioning. However, this universal rule may be intentionally broken depending on surfers' sociability. Ethnic and class differences based on historical processes can exist in oppositional relationships among surfers and are manifested by categories of accusation or identity (in São Paulo's case, local, haole, roots, prego, and playboy). However, this category attribution is contextual and interchangeable because surfers circulate between groups and beaches while searching for waves.
\end{abstract}

Keywords: surf, violence, identity, sociability

Resumo- - "Disputas territoriais, conflitos de identidade e violência no surfe." Manifestações agressivas de localismo são preocupações entre surfistas e se tornam conhecidas pela mídia especializada. O objetivo deste trabalho foi investigar este fenômeno a partir de um caso específico por meio de pesquisa de campo conduzida para a etnografia entre surfistas da cidade de São Paulo. Os dados foram obtidos por observação participante e entrevistas abertas. Os resultados mostram que os conflitos geralmente começam com disputas pelas melhores ondas. O surfe institui uma regra geral de acordo com "critérios de prioridade pela onda" baseada no posicionamento espacial. No entanto, esta regra pode ser desobedecida propositalmente, de acordo com a sociabilidade dos surfistas. Diferenças étnicas e de classe baseadas em processos históricos aparecem como relações de oposição reveladas por categorias de acusação ou identidade (no caso de São Paulo: local, haole, roots, prego e playboy). Entretanto, como os surfistas circulam entre grupos e praias a procura de ondas sua atribuição é contextual e intercambiável.

Palavras-chave: surfe, violência, identidade, sociabilidade

Resúmen- - Disputas territoriales, conflictos de identidad y la violencia en el surf." Manifestaciones agresivas de localismo son una preocupación actual entre los surferos y se están convirtiendo en conocida en los medios especializados. El objetivo de este trabajo fue investigar este fenómeno a través de um caso específico y investigación de campo para la etnografía entre surferos de São Paulo. Los datos fueron obtenidos a través de observación participante y entrevistas abiertas. Los resultados muestran que los conflictos generalmente comienzan por disputas de las mejores olas. El surf tiene una regla general de acuerdo a "criterios de prioridad por la ola" baseados en posicionamento técnico. Sin embargo, esta regla universal puede ser desobedecida a propósito dependiendo de la sociabilidad de los surferos. Diferencias étnicas y de clase sobre la base de los procesos históricos aparecem en relaciones de oposición reveladas por categorías de acusación o de identidad (en el caso de São Paulo: local, haole, roots, prego y playboy). Sin embargo, como los surferos circulan entre grupos e playas en busca de las olas su atribución es contextual e intercambiable.

Palabras clave: surf, violencia, identidad, sociabilidad

\section{Territorial disputes, identity conflicts, and violence in surfing}

The objective of this paper was to investigate a sports phenomenon known as localism ${ }^{1}$, which refers to local (native or resident) surfers' chronic aggressive reactions toward outsider or itinerant

\footnotetext{
${ }^{1}$ Words in italics correspond to field-specific expressions, as stated in anthropological writing.
}

surfers. This aggression may culminate in verbal intimidation, material destruction, and physical violence.

According to Dias (2009) and Alves Junior (2011), localism initially arose from native Hawaiians' reactions to the invasion and appropriation of their land by North Americans. As surfing became popular worldwide, a growing number of foreigners (especially Australians and South Africans) crowded Hawaiian beaches and waves, converting surfing from a ritualistic 
practice into a sport. Within this context, use of the Hawaiian word for white or foreign people, haole, spread throughout the surfing universe to name, from a local perspective, the outsider surfer.

Hawaii never lost its status as the ultimate destination for surfing (Hull, 1976; Soares, 2010). However, the crowd and numerous disagreements and acts discouraging surfing by foreigners generated a new conceptualization of the sport. Within the emerging global surf market, the search for perfect waves across the world became the ultimate surfing experience; this "lifestyle," spread through surf movies and magazines, is still in vogue and often conflicts with local lifestyles.

The specific aim of this text, which is the result of an ethnographic study, is to provide a detailed descriptive analysis of a specific case of localism to reveal the social logic that permeates this phenomenon. This method, based on an anthropological approach, helps us understand the complex reality of outdoor sports at a time when Brazilian physical education programs have begun to incorporate outdoor sports, show great enthusiasm for them, and often ignore the ambiguities and problems of these sports in favor of their benefits.

The study is composed of two parts: a description of São Paulo surfers' routines, followed by a discussion of how certain aspects of these routines relate to the issue of localism and to other Brazilian studies on the topic (Albuquerque, 2006; Alves Junior, 2011; Souza, Silva, Freitas, \& Rigo, 2012; Soares, 2010). According to Fonseca (1999) and Oliveira \& Daólio (2007), this contextualization, relative to other Brazilian studies conducted in different country regions (Ceara, Santa Catarina and Rio Grande do Sul), contributes to the present ethnographic study by helping to develop a more general interpretation of local data.

\section{Literature review}

By the time that Brazilian sports sociology and anthropology began to emerge within the context of soccer journalism and urban studies, Hull (1976) had already published research on the social aspects of surfing. In Brazil, the pioneering study, "O Futebol Brasileiro: Instituição Zero" (1977), by Simone Guedes, and the book, Universo do Futebol: Esporte e Sociedade Brasileira (1982), by Roberto DaMatta, revealed that the social aspects of sport of academic interest were related to national identity and the popularity of the soccer. Although surfing was also present in Brazil in the 1970s, the social analysis of sports in Brazil predominantly focused on the country's peculiar fascination with soccer.

Brazilian soccer spectator violence in the 1990s created concern; numerous public confrontations arose among soccer club supporters, some of which led to deaths. A study about this issue (Toledo, 1996) won the country's highest social sciences master's thesis award. The number of studies on the topic (Dos Reis, 1998; Murad, 1996; Pimenta, 1997) suggests its importance during this period.

Informed by Norbert Elias' interpretation of sports as a modulation of violence and part of the civilizing process (Elias \& Dunning, 1992), Brazilian sports researchers referred to violence as an archaism. Paradoxically, it was also predicted that violence would increase in the future because it was believed that urban societies were becoming increasingly violent (Dunning, 1992; Rifiotis, 2006). Violence was perceived as essentially negative and related to criminal behavior at the same time that it was perceived as intrinsic to sports practice.

On the other hand, during this period, the concept of sociability was appropriated by the Brazilian physical education field as something that was essentially good, based on the philosophy that all sports practices promote positive social interaction. However, Simmel (1983) stated that a purely harmonious group is empirically impossible to find. Sociability, according to Simmel - and as it is understood in this paper-implies conflict. From this perspective, any human manifestation has the potential for divergence, disagreement, and dispute.

Other studies inspired by Michel Foucault (1975) and Pierre Clastres (2004) suggested that what is considered violent varies in time and geographically. Circumscribed studies on specific types of violence and concrete subjects involved in situations that are considered violent could contribute to a more analytical and helpful approach of the issue as opposed to a generalist, exclusively theoretical, model.

Rifiotis (2006) believes that research on violence should consider its potential to combat the control and homogenization of behaviors that are imposed by entities or institutions in positions of power. In other words, the researcher should not judge violent situations based on common sense prejudice because such situations may represent processes of resistance against oppressive relationships and/or life conditions. The moderation and avoidance of violence, from this perspective, will only be attainable when the causes of and logic behind violence are understood and addressed.

Thus, the intention of this paper is to investigate violent manifestations, a classic issue in social sports studies, as they are presented within the relatively new context of Brazilian alternative sports, more specifically, surfing in São Paulo. Such sports have been added to the list of social studies concerns (Borges, 2007; Ferreira, 2003; Juodinis, 2006; Marques, 2010; Pimentel, 2005; Rocha, 2009; Souza, 2004; \& Uvinha, 2001) because their popularity in Brazil is growing. The increasing number of individuals performing those modalities in public places is producing new problems to address, such as the controversial and contentious aspects of surfers' sociability.

\section{Methodology}

This article ${ }^{2}$ is a product of a larger research project, "Surfing in Brazil: First Waves," which is funded by the Brazilian National Counsel of Technological and Scientific Development (Cnpq), and complies with the ethical standards of the Ethics Committee $^{3}$ of the School of Physical Education and Sports of the University of São Paulo.

\footnotetext{
${ }^{2}$ I am very grateful to Carolina Bonzo and Daniel Ramos for the data and English version discussion, to Priscila Campos and Mariana Martins for the theoretical discussion, and to Dirceu Silva, Flavio Benini, Juliana Saneto, and Alexandre Bastos for their help with the final revision. ${ }^{3}$ This study was approved under the registration code CEP/0202006/ EEFE/03032006, protocol number 69.
} 
This is an anthropological study, which employs an ethnographic method. This study includes a descriptive and interpretative analysis of human forms of being and living that favors the observed point of view (Geertz, 1989). The investigation involved extended coexistence, shared environments and routines, and significant interactions between the researcher and research subjects.

This research was conducted between the city of São Paulo and the coastline. São Paulo is not a coastal town, and I frequently noticed cars loaded with surfing equipment in the parking lot of my university institute (EEFE-USP). For convenience and the facilitation of closeness and coexistence, I selected interlocutors for this research according to Fonseca (1999) in her paper, "When Each Case Is not Just a Case: Ethnographical Research and Education" (based on a free translation):

The representativeness of the study subjects in ethnography is not treated the same way as in other branches of the social sciences [...] In typical [sociological] analysis, the "informants" are carefully chosen according to criteria (often statistical) formulated in advance and must be representative of the analytical categories (and/or ideal types) used in the initial formulation of the problem. The particular is used to assert or test some general statement. On the other hand, in classical anthropology, the researcher first chooses his or her "ground" and then seeks to understand its representativeness [...] that only come [sic] to light through the fieldwork. It is the particular data that pave the way for comprehensive interpretations. (p. 60)

I also considered other studies and verified that potential interlocutors were consistent with Hull's (1976) ${ }^{4}$ assertion that experience in the sport, frequency of practice, and recognition as a surfer by other surfers are important characterizations of a surfer as well as with the profile of Brazilian surfers described by Vasconcelos, Ramos, Steinman, Botelho, and Nahas (1997).

Vasconcelos et al. (1997) distributed 920 questionnaires through a Brazilian surfing magazine. Their analysis indicated the following characteristics of Brazilian surfers: 95\% were men; $55 \%$ were between 15 and 24 years old; $27 \%$ were living in the southeast region, whereas $26.9 \%$ were in the south; $56.6 \%$ had more than five years of practice; $69.1 \%$ considered themselves recreational surfers, $28.1 \%$ were amateurs, and $2.8 \%$ were professionals; and $78.3 \%$ used short boards (or pranchinha, in Portuguese). The average practice frequency of this sample was two to three times per week for two to three hours per session.

The main interlocutors of the present study were five recreational surfers who lived in the city São Paulo, were between the ages of 23 and 27 years, had surfed for 7 to 20 years, and went to the beach once per week on average. The interlocutors were not always together during observations, but the monitoring group was characterized by situations in which at least one of the interlocutors was present. As a result, the fieldwork was characterized

\footnotetext{
${ }^{4} \mathrm{He}$ created a Surfing Involvement Index (SSI) consisting of the equation $(\mathrm{SSI})=($ Years Surfing x 10) + Surfing Frequencies $+($ Proportion of Friends x 25).
}

by a shifting group composition. Other surfers, friends (and close friends called "brothers"), girlfriends, and family members were present and also provided data for analysis. Additionally, solitary trips and trips with strangers enabled the frequent "bate e volta," which is a roundtrip between the beach and home on the same day that allows coordination with one's work and/or study routine while supporting a self-imposed dedication to surfing.

Because I did not have experience with surfing, as opposed to Wheaton (2000), the participant observation strategy of analysis required learning (similar to Wacquant, 2002) how to surf. As a result, I would be able to watch and hear what surfers did and said while they waited for waves at the sea and to use my body as a source of experiential data to provide better descriptions. Thus, the analytical approach incorporated not only sports anthropology, but also anthropology that uses the body as a research tool and a vector of knowledge (Wacquant, 2002, p. 12).

In addition to seeing and listening to how surfers socialize, following the method of Wacquant (2002), who studied boxing as a kinetic culture, I extended the boundaries of the field research to learning how to surf with my interlocutors. Doing so increased my access to certain codes of conduct that are beyond consciousness, intrinsic to practice, and ultimately forbidden to spectators. As a result, this study was able to focus on the technical dimensions of localism, thus addressing a gap in the literature.

Surfing side by side with other surfers also meant participating in their trips. There were different arrival and departure times for surf trips, depending on the requirements of group members, the distance to the destination, and changes in sea conditions. A trip could be organized within minutes, and meetings in the middle of the night and absence from university classes were common.

The data were constructed in different localities in the state of São Paulo, mostly on the north shore, particularly the beaches of Boracéia, Juquehy, Baleia, Camburi, Maresias, and Paúba in São Sebastião County. The Pitangueiras and Tombo beaches, located in the south shore, in the city of Guarujá, were also included in the study.

In addition, open interviews provided a complementary understanding of localism through formal verbal explanations about what could not be experienced during fieldwork. Participant observations (Wacquant, 2002) were recorded in a field diary, and open interviews were audio recorded. Excerpts of the interviews were identified by random letters to preserve the anonymity of the participants.

\section{Results}

The city of São Paulo is located on a plateau. To reach the coast, one must go down mountain ranges by highways full of curves and long tunnels that cut through rock. Going to the beach is called "going down" or "descending" (descer in Portuguese), and returning to São Paulo is called "going up" or "ascending" (subir in Portuguese). These terms are not exclusive to São Paulo surfers but do appear frequently in their lexicon.

The surfers in this study usually travelled by car and gathered in the parking lot of EEFE-USP or at one of their houses. They 
placed their backpacks in the trunk and attached their boards to the car roof with rubber bands or ribbons with clips to ensure that the equipment was secured for the trip. Whenever possible, they took turns driving and split all expenses (gas, tolls, and food and accommodations on longer trips).

They often accessed the internet from computer labs available to students, sometimes more than once per day. They usually accessed it after every university class, and sometimes even during stressful or monotonous classes. For planning, the surfers used specialized websites that provide surf forecasts and real-time images and videos as well as a telephone service called the Disk Surf, which provides a daily recorded message about the waves for the state of São Paulo.

These tools facilitated surfing practice for São Paulo surfers because they allowed trips to be scheduled during suitable conditions for surfing. However, the surfers did not rely solely on this information when determining when to descend. For example, if a surfer knew that he would only have one break that week, he arranged the trip regardless of whether the waves would be good. Even if the sea was flat (the same word is used with a Portuguese accent) or bumpy (mexido, meaning the formation of waves is hampered by wind), going to the beach instead of waiting for better conditions could be justified according to the following logic: "We have to keep rowing for when the waves are there," "rowing is better than nothing; at least it keeps us fit," and "it is good to understand all types of waves; not every championship will present good waves."

When the waves were too small (merrecas) and the surfing required forçar a barra (colloquial Portuguese for when the waves are so small and weak that they barely can carry the weight of the surfer, who must project the board forward to continue running them), the decision to go to the beach was usually justified by invoking the healing properties of the sea. This excuse would help the surfer avoid being accused of being a "merrequeiro" (one that likes, prefers, or feels more comfortable with small waves).

Even if the surfers knew the conditions were bad, the hope that an unanticipated swell would come in or that a change of wind or tide would promote satisfactory surfing was pervasive. The surf session is called a sessão (session), queda, or caida. The last two expressions are related to the verb cair, which means "to fall" in Portuguese. However, in this context, cair no mar means "to enter the sea." For example, surfers often ask each other the following questions: "vamos cair?" (Should we fall?) or "que horas você vai fazer a queda?" (What time are you going to fall?).

Although there was consensus about smaller waves and long flat periods (when they say the sea turns into a piscina (pool) or lago (lake) during the Brazilian summer and larger waves in the winter or during cold fronts and storms at sea, the surfers said, "We never know when the swell will come, or how. So we never know how much we need to be prepared physically and mentally. We cannot waste an opportunity to be at sea, even if the waves are not ideal."

In addition to being sufficiently fit to catch waves, as Hull (1976) noted, surfers must have time available when waves are present. The surfers' schedules did not always permit surfing, and having an unavoidable commitment when there was a good swell appeared to be a source of distress for the surfers. If a swell was identified on a website, an exchange of emails, text messages, and calls would begin: "Você viu? Você vai descer?" (Did you see that? You gonna descend?). In their fieldwork in the Rio Grande in southern Brazil, Souza et al. (2012) noted that the equivalent slang would be, "Partiu pro surf?" (Departure to surf?).

Understanding how to change an appointment, exchange work shifts, or find a substitute was a constant concern among the surfers because "the swell doesn't always come on weekends!" Most surfers were students and interns and had schedules that were flexible enough to allow surfing. In addition, physical education was considered a potentially autonomous professional field that would continue to allow alternative schedules that complement the surfing lifestyle.

A new swell and speculation about its characteristics, the possibilities of each surfer's performance, and the uncontrollable behaviors of nature incited excitement about the potential risk. The surfers gave this combination of sensations the neologisms "adrenante" or "adrenado," which are similar to "adrenalizing" or to "be adrenalized":

The surf has this one thing, from my point of view, which you might have heard, but I don't know if you felt that because you started surfing later. When you're a kid and start surfing, you become very euphoric, happy, energized, silly. When you take the first wave, the feeling of getting to surf is a very strong feeling, a shiver that runs through the body. It's the adrenaline. And even today, when I know that the sea is perfect, I feel that same feeling. When you know there are waves, it refers to your memories of surfing. When you know you will surf, you revive the memory of everything you lived for surfing. When you see that a swell will come, it gives you a flashback of all the excitement, the happiness of a good surfing day and also the euphoria of cabulosa (gnarly, dangerous but good) situations. And with time, you learn to enjoy even the cabulosa waves. It makes you adrenado even before you get on the beach to see with your own eyes. (DR)

Adrenado can mean excited by the possibility of a very good queda but also worried and alert about situations that are cabulosa. In addition to the considerations inherent in selecting which beach to visit (aspects affecting the wave type, such as the shore position, moon phase, board tides, swell direction, wind type, bottom formation, channels, water temperature), these surfers performed what they called a check each time that they arrived at the São Paulo coast. According to Souza et al. (2012), conféris, which is a playful form of the verb "confer," is used by Cassino beach surfers to indicate the surfers would drive through and observe the size and number of waves per set (série), and time between sets (called calmaria, which means calmness) at different beaches or portions of a long beach to determine which waves were most suitable for surfing at a particular moment on a particular beach.

Because they lived in São Paulo, the observed group of surfers often completed the most surfing sessions possible in 
a day and pursued the greatest number of waves per session to optimize practice time. Whereas Brazilian surfers who live by the coast surf two to three hours, three times per week (according to Vasconcelos et al., 1997), the surfers observed in this study surfed once or twice per week, and frequently three times per day during the weekends, for three or more hours per queda. It was common for them to arrive at the beach at sunrise and leave at sunset.

When São Paulo surfers arrived at the shore, they were anxious to confirm whether the conditions observed on the websites had changed while they were travelling. They strained through the car windows to see whether, where, and how the waves were breaking with enthusiastic expressions, yells of excitement, eager smiles, guesses about the best place for sessions, jokes about the skills or situations experienced by others, and challenges.

When the swell was large, the surfers would stop the car for several minutes to watch the wave formation, concentrating and noting every detail, either silently or in discussion. When a consensus was reached and a spot was selected, another routine began: the boards were removed from the car and waxed, the fins and leashes were fixed and checked, and a short warm up or stretching on the sand commenced as they watched and evaluated the waves. Each surfer asked for blessings in their own way, mixing Catholic references with creative conceptions of sea divinity, in reverence and respect or as a request for consent and protection in their search for the best waves:

I'll start praying to Neptune, to pray for someone. I don't know, I thought about it today. He is a god... of the sea. I'm being silly... However, it is my feeling about the sea... Not because he is a god, it is because he is the sea, which is divine. All life comes from the sea. I would like to thank everything that I can feel in the sea. I have experienced so many wonderful things, and some other inexplicable things that are cabulosa. You learn to have respect and also to have a smile on your face for what just happened there. When you force a maneuver or a tube and suddenly, out of nowhere, you go out or back; sometimes it seems that you lose your body weight completely and you have no body, you are just the wave motion [...]. (DR)

Better waves, understood as ideal for surfers' performance, were called perfeitas (perfect) and perceived as magical. However, in the crowd, different surfers' expectations about a sacred relation with the sea could become a dispute. Quite often, other surfers' presence was considered by São Paulo surfers when deciding which beach to surf or in which spot to paddle. For example, good wave beaches might be too crowded, producing the potential for conflict because waves might be contested and shared among a large number of surfers. These São Paulo surfers may prefer a surfing spot where they are able to catch more waves, even if the shapes of the waves are inferior. Discussion of such situations brought to light the different categories used by the interviewees to classify other surfer groups. Beaches or parts of a beach potentially full of locals, haoles, pregos or playboys were avoided. Below, the last two terms are explained in more detail.

\section{Surfing is no longer only a "playboy" thing}

From the 1930s to the 1950s, surfing equipment and references were brought to Brazil by young people from the upper social classes who were able to travel around the world (Dias, 2009). Hull (1976), in his study about Santa Cruz surfers, and Albuquerque (2006), in her study on Fortaleza surfers, suggest that some characteristics of surfing practice, such as the preference for risky sports, concerns about environmental awareness, quality of life, and mastery of technological innovation, may be limited to a privileged social strata that is able to frequently consume products related to surfing.

Surfing equipment and clothing become more technologically advanced each season. However, this frequency of consumption was more of an aspiration than a possibility for the surfers in this study. What Wheaton (2000) called "denial-style" among British windsurfers is also common in São Paulo; thus, the interviewed surfers were reluctant to select their clothes according to surf fashion. Although they admitted buying and wearing branded clothes, they did not want to be associated with people who value branded purchases, and they attributed such high consumption to two poles of activity: playboys, who are inauthentic surfers only interested in fashion, and professionals, who consume regularly as a consequence of regular competition:

Consumption is more a result of high-level performance, of wanting to improve the sport and be professional. However, if you have a board and laminate it well, you will surf with it the rest of your life. (DR)

Typically, the surfers in the study did not have a quiver, or a set of boards with characteristics geared toward different wave conditions. Instead, each surfer had one board called a coringa (joker in Portuguese) that was widely adaptable to different wave conditions and is an object of constant care and maintenance.

Surfers who did not have much money purchased used boards that were bought directly from friends or shops. A used board, calculated for wear, can be acquired for a fifth of the cost of a new board. For example, I bought a used board that cost approximately one hundred and twenty reais, whereas new boards cost approximately five hundred reais. Purchasing less expensive shapers was another option.

Not all surfers had a car, and even those who owned a car were not always able to afford gas and tolls for the descent. Many times, the owner of the car depended on his brothers splitting the bate-e-volta to continue to surf frequently. In most cases, surfing occurred because it was prioritized.

A surfer does not stop going to the beach if he is broke, busy, or lacking time with his family because we feel that the friend who invited us to descend needs us to surf. If you say "no," he will stop counting on you. At other times, you may need him to help you surf. This is the way of life in São Paulo. A group of friends must go with you, not only for social integration, but because of the financial issue. If you say "no," you will not be considered in the future. It creates an even friendship. He does it for you and you do it for him. One sacrifices for the other, even 
though it is not a sacrifice because it's a pleasure to go surfing. However, I have been repeatedly invited to go surfing when I have to work, so I have to ask someone to swap with me at the trampo [at work], which is not pleasant. The coordinator gets mad, and sometimes I lose money. That's why I call it sacrifice, but if you don't have a car, this is what you have to do. (CB)

Among the surfers who did not consider themselves upper class, had low-paying jobs, or were beginning their careers, the price of going to the beach seemed to serve as a currency reference. Many surfers avoided other items of consumption and activities to afford items related to surfing, as illustrated in the dialogue below:

\section{JB: Let's go!}

MS: Are you crazy? This party costs two bate-e-volta.

Like Wheaton (2000), Brasil and Carvalho (2009) have identified surfer speech and attitudes that do not support the image of the surfing consumer. Although the surfers observed in this study recognized that surfing was not accessible to any interested paulistano, or São Paulo inhabitant, they sought to differentiate themselves from those who could be classified as playboys.

The observed surfers complained of disengagement and the mischaracterization of the sport and blamed playboys for the crowding problem and for interfering with waves by handling their equipment clumsily.

Despite sometimes wearing branded clothes, the surfers said that they only did so because branded products are more durable and suitable for surfing than lesser known brands. Moreover, they considered themselves the opposite of playboys for whom surfing would be a status symbol or a style to be displayed outside of the universe of surfing (i.e., "because it is cool" or to "get some chicks"). Instead, they considered themselves roots (they used the English word with a Brazilian accent), which refers to individuals who are simple and authentic.

The roots are similar to what Hull (1976) and Wheaton (2000) termed a core group or core participants. According to these authors, core participants set the tone for the sport through their highly technical level of dedication and commitment to ideologies that accompany the practice. According to my interlocutors, the roots behavior also entails material detachment:

Today I needed a fin key because I lost the one that came in my kit and couldn't borrow one. So I went to a surfshop to buy one, and the guy at the store told me that the manufacturer is no longer selling separate fin keys and that I would have to buy the entire kit. I was already out there and very angry, and he said, "Wait." He then grabbed a pair of very expensive Oakley shorts and took a wax comb from the pocket with an embedded fin key, which was very cool. He pulled out the key and gave it to me. I asked how much it was, and he told me, "Oh, it's nothing. The guys who buy these shorts don't know what it is used for, whatever...." Gee, this guy is roots! (DR)
The roots provide a direct contrast to the playboys. There are also the pregos, meaning unskilled persons who are considered talentless or do not sufficiently dedicate themselves to practicing or understanding surfing. They pay exorbitant prices for branded boards that are available in shopping malls. Unnecessarily expensive boards that are well preserved indicate that they are not frequently used and that the person does not know how to surf but wants to appear to be a surfer for its supposed appeal outside the sports universe. A similar situation was noted by Wheaton (2000) with regard to windsurfing:

Despite the centrality of windsurfing equipment to the activity and the expenditure required to get involved in the sport, members could not "buy" their way into the core of the subculture. In Bourdieu's terms, the relationship between economic capital and (sub)cultural capital is more complex than a direct exchange. An antimaterialism ethos was evident from the windsurfers' attitudes to those individuals who purchased equipment they considered to be beyond their proficiency or who tried to demonstrate their subcultural membership or status just by displaying their equipment [...] The windsurfer with all the expert equipment was not respected unless he or she shined out on the water. (Wheaton, 2000, p. 263)

Similar to windsurfing, a surfer's status is not determined by the money he or she spents on equipment but rather by his skill, prowess, and commitment to the practice. Because São Paulo surfers do not live at the beach, they must be skilled to avoid being perceived as a playboy, prego, or haole.

\section{When the sea is territory}

The rules of the sport are simple: paddle out into the lineup, catch a wave, stand up on the surfboard, and do the best you can (Hull, 1976).

Although I acknowledge that Hull's (1976) summary of surfing techniques serves rhetorical purposes, I would like to state, from my point of view as a neophyte, that surfing is not simple. The author was already experienced in surfing and wrote in a time when surfing was not as popular as nowadays. In another paper (Bandeira \& Rubio, 2011), I demonstrated how complex each body action is. However, in the present study, I focused on the rules of surfing interaction.

Because the experiences of São Paulo surfers are associated with territorially unrestricted practice sessions when circulating among several beaches, they have to act according to a general code of conduct. The most general rule for surf spots is the "wave priority criteria" that define who has the right of way for catching a given wave when access is disputed by two or more surfers.

Although many surfers who want to support sports friendship believe that a worldwide "tribe" of surfers exists, this belief is marked by idyllic hedonism. In many cases, the ideal of harmonious contact with nature transforms into hostile competitiveness at sea. 
As a consensus and a universally recognized surf code of conduct, a surfer's location sets the priority for a wave, with the surfer closest to the peak (pico) having the right of way. The waves are either rights or lefts. If you are paddling for a right wave and a surfer on your left is also paddling for it, he needs to wait until you quit or signal to him that you are going to quit. The wave "belongs" to the person who is best positioned and "more within the wall of the wave" or "closest to the pico."

Pico (peak) is a frequently used expression that has different meanings, each of which is related to localism. Its first meaning refers to the portion of the wave that first breaks and propels the surfer. The drop is critically closer to the pico because the time limit between the possibility of a drop (putting one's feet on the board) and a strong wipeout (which happens when one falls with the wave lip) is shorter. By contrast, the critical drop is more difficult and radical to achieve because it involves greater risk, and anyone who dares to take a greater risk has priority.

In its second sense, a pico is a portion of a beach and can be named as a point of reference from the sand, such as a geographical formation, a commercial tent or a building located in front of it. Souza et al. (2012) identified six main picos on Cassino beach and stated that the harbor engineering interventions that destroy picos each year pose a major challenge for the surfing community. This topic is particularly important in Brazil because most beaches are sand bottomed, so fixed picos such as beach bottoms on rock or reef are rare.

For Albuquerque (2006), the pico is where the waves break, but the term does not simply denote position. It has a "socio-spatial and symbolic connotation for surfers as it represents not only the locus where the waves break, but the entire physical and social environment that is suitable and used by surfers: the land-sea territory" (p. 10). A beach can have several picos. Alves Junior (2011) adds that the number of surfers in a pico both encourages paddling to the pico and repels surfers. It may be a sign of good waves and/or a place for trouble because of wave disputes, as indicated by his interlocutor, who is a local:

I'm there every day, and I know where the wave will break, I know where the stream is, and where to go. This is the place that the local knows, and he knows what he is doing. He does not go there blind, you understand? The guys enter and they are blind; they do not know where to go like us. (Alves Junior, 2011, p. 111)

The ideal local is a beach native or resident. However, São Paulo surfers who have relatives, rent or own a house on a beach, who spent time there as children on weekends and holidays, who learned to surf there, or who have established long-term relationships with locals and frequent the beach regularly can also be considered locals. More than once, I heard remarks such as, "Today is a good day in Camburi, but I can't handle those locals," and "On a summer holiday weekend, everywhere will be crowded, so it is better going to Tombo because there I'm local."

There is a progression of belonging to a place that can be developed through surfing. As Alves Junior (2011) states, face-to-face relationships and a concern for beach issues determine who is local.

According to Alves Junior, at a pico, surfing territoriality is mobile, fluid, and flexible. It arises from ocean and wind conditions that change constantly and is bounded by the social interactions among surfers. Therefore, a pico is created by waves and social relations.

From the studied surfers' point of view, respecting local surfers who make a peak known is a part of surfing etiquette. Showing such respect includes not disputing waves and not acting aggressively with locals. Usually, the best pico of a beach is known and reserved symbolically and physically by and for local surfers. Thus, localism can occur in the individual dimension and in the collective dimension. For example, a local can ignore the wave priority rule if the surfer with whom he is competing for a wave is not another local. There are certain picos where the local surfers, as a group, do not allow haoles, and there are locals who claim the entire beach in a third sense of pico, especially if it is short in length, has few beach breaks, and is difficult to access.

When learning how to surf, I was warned not to enter certain local picos and to quit waves if I was competing with people who seemed local by their attitude and conversation. Sometimes, when paddling to a pico at beaches where there were few options from which to choose, I heard shouts such as "Get out haole" and "Locals only."

Alves Junior (2011) calls this symbolic violence, according to Dunning's (1992) classification. Similar to Alves Junior, I did not observe the most extreme manifestation of localism: physical aggression, which is what Dunning would call "real violence." However, Alves Junior (2011) and I both heard such reports about other beaches:

If you try to go in there with the board, per track, the locals use a sling and throw marbles on your surfboard to put a hole in it. Sometimes they do not hide. They go there to interrupt you on the track and tell you not to get into the water and even threaten you, saying they will damage your car. If you react, a treta [fight] can start right there. (MW)

Hull described this phenomenon in 1976 as follows: "The social problem referred to most often by surfers is the over-population of surfing areas. The popularity of surfing has created an increased demand on the limited number of rideable surf spots." Hull also provided the following definition:

Locals are individuals who make up the group of surfers who consider a particular beach "theirs." This sense of territoriality is very important within the surfing scene. A particular beach is a symbol to the group of their "home" and their unity. They surf there whenever possible, lounge there whenever they can, party there regularly, and sometimes sleep there (Hull, 1976).

Although Hull noticed graffiti near surfing areas with messages such as, "Valley Bug Out!," "No Tourists Allowed," "Surfers Rule!," and "RS0 is in Control!," he argued that fighting occurred rarely and that status was determined by competitions on surfboards rather than "with fists." In Hull's (1976) study, he noted that "locals do not physically stop anyone from using 'their' beach, but tourists and most visiting surfers alike are expected to accept their status as unwelcome 'guests,' if not intruders." 
Moreover, according to Soares (2010), we must be aware of how the Brazilian specialized media have reported on localism by considering only one point of view. One such example is the colonial perspective of some magazine publishers, who feel that their surfaris have been disturbed by locals. Below, I cite an excerpt from the magazine analyzed by Soares:

It's a shame that on certain days, the surf is impaired by the presence of people who call themselves surfers but still carry the ignorance and aggressiveness of thugs. Of course, many local people strive to change this mindset. We at Fluir, Surf More and Holysport support any effort to extinguish any localism in any part of Brazil (2010, p.152).

Soares (2010) argues that it is important to note the contrast between global and local representations of surfing. The representations created by magazines are Americanized, influenced by profit, and global, whereas those created by the locals of certain beaches are alternative experiences that are frequently ignored by magazines. This contradiction is evident in the denouncement of localism in the name of the sportification, growth, and popularity of surfing, which contrast with other published articles that complain about crowded beaches. Therefore, it is important to identify the types and causes of conflicts that arise among global and local surfers.

The appropriation of surfing in southeastern Brazil (especially in São Paulo) as a particular "caiçara" lifestyle is another example. The "caiçaras" are rustic coastal communities that originated of a mixture of races and groups such as: survivor indigenous peoples, poor Portuguese individuals, and runaway slaves. The term "caiçara" often refers to the traditional fishermen populations that evolved from this mixture.

According to Adams (2000), the caiçara way of life consists of subsistence agriculture, fishing, crabbing, and raising chickens and pigs. In the 1940s, this lifestyle was characterized by simple shelters hidden among the foliage of the beachfront:

The term comes from the Tupi-Guarani caá içara [...], which was used to denote the stakes placed around the villages and the corral made of tree branches stuck in the water to surround the fish. Over time, it became the name given to the huts built on the beaches to house canoes and gear for fishermen, and later, to [...] all individuals and coastal communities in the states of Paraná, São Paulo, and Rio de Janeiro (Adams, 2000, p. 146).

However, new roads and highways providing access to the north coast of São Paulo in the second half of the Twentieth Century reflected socio-economic transformations. Because of the decreased number of fish available for artisanal fishing due to pollution and predatory industrial fishing, the caiçaras began selling their lands on the beachfront to buy engines for their boats. The growth of tourism has led those fishermen who were not able to sell their land to seek low-paying jobs, such as working as janitors or waiters, in beach services at hotels, or in sales at shopping malls.
According to Suzuki and Lopes (n.d.), the imposition of an urban-industrial society continues to threaten the caiçara lifestyle, and their land continues to be taken. A "youth caiçara culture" has emerged in response to this conflict. Some of these youth fight to defend their traditions, whereas others reject their caiçara identity.

This study revealed that conflicts concerning localism often emerge in relation to the rule of priority for a wave. This rule can be disregarded intentionally when paddling beside a better positioned surfer by "dropping in" (rabear in São Paulo, rabeirar in Florianópolis, and enrrabar in Fortaleza) on the wave in front of him. Another possibility is to paddle around (dar a volta) the person who has priority, taking his place and dropping in on the wave before him.

Although surfing seems very silent from the perspective of the sand, on the outside, there is often shouting. On the one hand, a performer's drop and his capacity to surf may be encouraged with shouts such as "Woohoo," "Go," and "Paddle, paddle, strongly." On the other hand, screams enforcing wave domain, such as "Aêêe," "Get out," "That's mine," and "Me" may also be heard.

If intentional, rabear can be the cause of violent reactions because it is considered an offense. In general terms, this occurs when one surfer judges another surfer as technically inferior or undeserving or as "wasting" a good wave. Two haoles or two locals can be involved in such situations, which may lead to verbal and physical aggression. Given the unequal division of the number of waves among positioned surfers, a surfer who pega todas (catches all the waves), called fominha ("little hungry" meaning greedy in Portuguese), can irritate other surfers.

When performed by a haole, rabear normally involves trying to catch a greater number of waves to optimize a surfing session, which provokes warnings. The surfer justifies this because of the great effort they have to make to be there surfing, as described above. If this behavior is persistent, threats ensue, and the haole may be expelled from the water. Finally, in extreme cases, physical aggression results.

In cases of localism, locals do not follow the wave priority rule when outsiders who are perceived as "playboys" or invaders are involved. The local is not always a native, but he understands that he has higher priority to access the waves because the beach is his home by choice. In contrast, the haole or tourist is perceived as someone who wants to use the beach temporarily and give nothing in return. No surfer voluntarily calls himself a haole; it is an undesirable label, and thus, it is not an identity but rather a category of accusation, similar to the terms playboy and tourist:

Of course there are radicals who close the beach and don't want to know you. However, in general, I think the question is not against the guy who has money. Like the guy who was born into a poor family, he is not guilty of being born into a family with money. Now, what cannot happen is to have a "playboy" attitude, you know? If the guy is rich but has humility, is educated, takes care of the beach, goes surfing and does not bother anyone, he is just a surfer. (FN) 
Therefore, São Paulo's surfers are constantly defending themselves from local accusations that they are financially privileged relative to the locals. However, locals are not always surfers who are rustic or relatively poor; some locals own businesses or family land. Thus, whether someone is a caiçara or a surfer from the upper, middle or lower class there are different wave negotiations.

Thus, localism can also be seen as a way of distributing sea wealth or, more precisely, the number of waves per surfer. As Soares (2010) states, the more waves there are, the smaller the possibility of conflict is. In this sense, localism is also a mechanism of regulation and organization.

Corroborating this argument, Albuquerque (2006) described localism in Fortaleza as more intense in smaller communities whose members are not able to take surf trips frequently. According to the interlocutors in the present study, more conflicts occur when waves are rare or small in size because it is easier to paddle outside and the sea becomes more crowded.

\section{Discussion}

Surfing appears to be a common activity between some caiçaras. Localism can be viewed as a caiçara resistance mechanism for participating in and dealing with the surrounding society. Thus, localism can be considered social class opposition and, to a lesser extent, an ethnic issue. Localism is magnified by its physical manifestation: to drop in or rabear. Non-accidental rabear is directly related to how a surfer sees himself on the beach and in the sport and how he is perceived by the different surfing groups that are formed under different circumstances.

Media reports indicate that locals threaten outsiders' lives. I do not deny that such conflicts can result in a combination of localism and criminal behavior. However, some outsiders provoke and contribute to fights, some locals are against fights and denounce them, and some haoles understand the complexity of the situation:

I think it is crucial to know how to "come and go." There is localism because they know that other people are surfing "their" waves or getting "their" girls. So we have to learn to respect and ensure respect is returned by showing our value, recognizing the value in others, and relating to the locals, for example, by saying "good morning." Nobody enters your home, opens your refrigerator, and takes your food without talking to you. No one enters your house without ringing the doorbell and greeting you first. This is the same situation. (AH)

This excerpt illustrates that understanding, respect, friendship, and hospitality do exist among locals and non-locals.

Learning from a local is highly valued by the São Paulo surfers observed in this study and is understood as being roots. Staying overnight with locals, eating with them, and accompanying them on fishing and surfing trips are perceived as experiences of maximum simplicity and integration with nature and the native population.

Through a local interlocutor, Alves Junior (2011) clarified that there are differences of opinion and action among locals.
The conception of being a local presented by Alves Junior also entails a commitment to issues such as environmental preservation and resistance to uncontrolled urban growth.

[The local] uses what? Authority? When you have power [...], you make people do what you want without having to use force. It is for something you did or for something you are. The local is the guy who is at the pico every day. If he sees something wrong, he tries to solve it, and he is the guy who is respected. [...] It does not mean that the guy wants to fight (p. 75) .

Being local, therefore, can also be understood as having a conciliatory attitude.

Considering the data here, in contrast to other fieldwork on the subject, I argue that localism is highly referential, not only in geographical terms but also with regard to ethnic groups and social classes.

According to Bourdieu (1990), a habitus may contain several different meanings at the same time. Therefore, this text highlights the importance of Bourdieu's warning about avoiding a social analysis of sports that does not consider the social diversification of practitioners, who practice at different levels and have distinct styles and relationships to the sport.

\section{Conclusions}

Competing interpretations of the same modality indicate the occupation of different social positions by its adherents. However, those positions are never static, especially in alternative leisure contexts in which the rules are not elaborated in a formal written tradition, and are practiced in natural spaces that are public and uncontrollable. In surfing, conflict arises because waves are not always available.

Regarding localism and its technical dimension, the wave priority rule, I argue that the different methods of dealing with disputes (by locals, haoles, playboys, roots, and pregos) demonstrate that surfing nomenclature is negotiable and interchangeable. A local here is a haole there, and a prego today may develop experience and thus no longer be called a prego. Someone may be a playboy depending on who says so.

Therefore, the ethnographic data herein present a critical perspective on unilateral studies that are biased either against or in favor of outdoor sports and do not consider the plurality of thinking and acting models that exist among different groups of practitioners and within groups. Localism cannot be viewed a priori as gratuitous violence. It must be understood as a socio-historical complexity that is case specific.

\section{References}

Adams, C. (2000). As populações caiçaras e o mito do bom selvagem: A necessidade de uma nova abordagem interdisciplinar. Revista de Antropologia, 43(1), 145-182.

Albuquerque, C. (2006). Nas ondas do surfe: Estilo de vida, territorialização e experimentação juvenil no Espaço urbano (Master's thesis). Universidade Federal do Ceará, Fortaleza, Brazil. 
Alves Junior, C. (2011). O pico dos surfistas e os surfistas do pico: Sociabilidade, territorialidade e surfe na Vila Dos Peixes (Bachelor honors monography). Universidade Federal de Santa Catarina, Florianópolis, Brazil.

Bandeira, M., \& Rubio, K. (2011). Do outside: Corpo e natureza, medo e gênero no surfe universitário paulistano. Revista Brasileira de Educação Física e Esporte, 25(1), 97-110.

Borges, R. (2007). Corrida de Aventura e risco: Um estudo etnográfico (Master's thesis). Universidade Federal do Rio Grande do Sul, Porto Alegre, Brazil.

Bourdieu, P. (1990). Programa para uma sociologia do esporte. In P. Bourdieu (Ed.), Coisas ditas (pp. 207-220). São Paulo, Brazil: Brasiliense.

Brasil, F. K., \& Carvalho, Y. C. (2009). Pescadores artesanais, surfistas e a natureza: Reflexões a partir de um olhar da educação física. Movimento, 15(1), 217-239.

Clastres, P. (2004). Arqueologia da violência: Pesquisas de antropologia política. São Paulo, Brazil: Cosac \& Naify.

DaMatta, R. (Ed.). (1982). O universo do Futebol: Esporte e sociedade brasileira. Rio de Janeiro, Brazil: Pinakotheke.

Dias, C. (2009). O surfe e a moderna tradição brasileira. Movimento, 15(4), 257-286.

Dos Reis, H. (1998). Futebol e sociedade: As manifestações da torci$d a$ (Doctoral dissertation). Universidade Estadual de Campinas, Campinas, Campinas, Brazil.

Dunning, E. (1992). As ligações sociais e a violência no desporto. In N. Elias \& E. Dunning (Eds.), A busca da excitação (pp. 327-354). Lisboa, Portugal: Difel.

Elias, N., \& Dunning, E. (1992). A busca da excitação. Lisboa, Portugal: Difel.

Ferreira, L. F. (2003). Corridas de aventura: Construindo novos significados sobre corporeidade, esportes e natureza (Master's thesis). Universidade Estadual de Campinas, Campinas, Brazil.

Fonseca, C. (1999). Quando cada caso NÃO é um caso: Pesquisa etnográfica e educação. Revista Brasileira de Educação, 10, 58-78.

Foucault, M. (1975). Vigiar e punir: História da violência nas prisões. Petrópolis, Brazil: Vozes.

Geertz, C. (1989). A interpretação das culturas. Rio de Janeiro, Brazil: LTC.

Guedes, S. (1977). O futebol brasileiro: Instituição zero (Master's thesis). Universidade Federal do Rio de Janeiro, Rio de Janeiro, Brazil.

Hull, S. (1976). A sociological study of the surfing subculture in the Santa Cruz area (Master's thesis). San Jose State University, San Jose, CA. Retrieved from http://www.lajollasurf.org/srf_thes.html

Juodinis, G. (2006). O excursionismo e o gosto pela natureza (Master's thesis). Pontifícia Universidade Católica de São Paulo, São Paulo, Brazil.

Marques, R. (2010). Cidade lúdica: Um estudo antropológico sobre as práticas de Parkour em São Paulo (Master's thesis). Universidade de São Paulo, São Paulo, Brazil.

Murad, M. (1996). Dos pés à cabeça: Elementos básicos de sociologia do futebol. Rio de Janeiro, Brazil: Irradiação Cultural.

Oliveira, R., \& Daólio, J. (2007). Pesquisa etnográfica em educação física: Uma releitura possível. Revista Brasileira de Ciência e Movimento, 15(1), 137-143.

Pimenta, C. (1997). Torcidas organizadas de futebol: Violência e auto-afirmação, aspectos da construção das novas relações sociais. Taubaté, Brazil: Vogal.

Pimentel, G. (2005). Risco, corpo e socialidade no vôo livre (Doctoral dissertation). Universidade Estadual de Campinas, Campinas, Campinas, Brazil.

Rifiotis, T. (2006). Nos campos da violência: Diferença e positividade. Retrieved from http://www.cfh.ufsc.br/ levis/downloads/artigos/ NCVDP.pdf
Rocha, V. (2009). Ninguém se arrisca à toa: Risco e emoção no esporte radical base jump. (Doctoral dissertation). Universidade Estadual Rio de Janeiro, Rio de Janeiro, Brazil.

Simmel, G. (1983). A natureza sociológica do conflito. In E. Moraes Filho (Ed.), Simmel (pp. 121-134). São Paulo, Brazil: Ática.

Soares, R. (2010). Localismo e desbravamento do Brasil: Duas dimensões do espaço na cobertura jornalística de esportes radicais. Revista Eco-Pós, 13(2), 143-162.

Souza, F. (2004). O imaginário no rafting: Uma busca pelos sentidos da aventura, do risco e da vertigem. São Paulo, Brazil: Zouk.

Souza, T., Silva, M., Freitas, G., \& Rigo, L. C. (2012). "Partiu pro surf": Memórias e amizades na Praia do Cassino - RS. Revista Didática Sistêmica, Especial(1), 78-94.

Suzuki, J. C., \& Lopes, A. P. (n.d.). Vida do jovem caiçara na Prainha branca: Modo de vida e representações sociais. Retrieved from http://observatoriogeograficoamericalatina.org.mx/egal12/Geografiasocioeconomica/Geografiadelapoblacion/22.pdf

Toledo, L. H. (1996). Torcidas organizadas de futebol. Campinas, Brazil: Autores Associados.

Uvinha, R. (2001). Juventude, lazer e esportes radicais. São Paulo, Brazil: Manole.

Vasconcelos, E., Ramos, V., Steinmein, J., Botelho, L., \& Nahas, M. (1997). Características demográficas e estilo de vida de surfistas brasileiros. In Anais do $1^{\circ}$ Congresso Brasileiro de Atividade Física \& Saúde, Florianópolis, Brazil.

Wacquant, L. (2002). Corpo e alma: Notas etnográficas de um aprendiz de boxe. Rio de Janeiro, Brazil: Relume Cumará.

Wheaton, B. (2000). "Just do it": Consumption, commitment, and identity in the windsurfing subculture. Sociology of Sport Journal, $17,254-274$.

\section{Author's note}

Marília Martins Bandeira is a doctoral student affiliated with the Department of Physical Education, College of Physical Education, State University of Campinas, Campinas, São Paulo, Brazil.

\section{Address:}

Alameda Jundiaí, 235, Santana de Parnaíba 06542-085 São Paulo SP, Brazil

Phone: (11) 41534771/(11)984204994

E-mail: martins.marilia@yahoo.com.br

\section{Acknowledgment:}

This study was presented at the 2013 International Congress of Human Movement Sciences and the São Paulo Symposium of PE

Manuscript received on March 29, 2013

Manuscript accepted on September 30, 2013

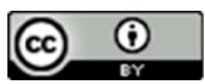

